\title{
STUDI PENGGUNAAN PUPUK BOKASHI (KOTORAN SAPI) TERHADAP TANAMAN PADI, JAGUNG \& SORGUM
}

\author{
Iswahyudi $^{1)}$, Aqidatul Izzah $^{2)}$, Ainun \\ Nisak $^{3)}$ \\ 1,2,3 Prodi Agroteknologi Universitas Islam Madura \\ e-mail : iswahyudi@uim.ac.id ${ }^{1)^{*}}$, aqidatulizzah027@gmail.com ${ }^{2)}$, \\ ainunnisa168@gmail.com ${ }^{3)}$
}

\begin{abstract}
ABSTRAK
Kesuburan tanah yang dikelola dengan melibatkan bahan organik, meningkatkan sifatsifatnya. Bokashi kotoran sapi merupakan pupuk organik yang dapat menjadi digunakan untuk perbaikan tanah berkelanjutan. Tinjauan ini memberikan informasi yang ada mengenai pengaplikasian bokashi khususnya kotoran sapi pada tanaman padi, jagung dan sorgum. Selain membahas pengaplikasian bokhasi untuk produksi padi, jagung dan sorgum, ada pula pembahasan mengenai kandungan bokhasi dan efek pemberian bokhasi pada tanah. Pemberian bokashi pada tanah menjadi solusi utama untuk mengatasi masalah untuk produksi tanaman secara berkelanjutan. Sejumlah hasil penelitian di Indonesia telah terbukti memiliki efek menguntungkan dalam menggunakan bokashi. Bokashi merupakan teknologi yang dapat mengubah sistem pertanian berbasis kimia menjadi sistem pertanian yang lebih alami (organik). Dengan demikian, bokhasi dapat meningkatkan kesuburan tanah dan produksi tanaman. Selain itu, dengan adanya sumber bahan baku melimpah dapat dimanfaatkan petani di daerah-daerah untuk membuat bokhasi.
\end{abstract}

Kata kunci: Bokashi, Kotoran Sapi, Padi, Jagung, Sorgum.

\section{PENDAHULUAN}

Sejauh ini sektor pertanian masih memegang peranan penting dalam pembangunan perekonomian nasional. Salah satunya yaitu sebagai pemasok kebutuhan pangan nasional. Pangan adalah kebutuhan yang sangat penting bagi manusia, sehingga harus kesediannya harus terjamin. Intensitas penanaman secara terus-menerus dengan menggunakan pupuk kimia tanpa ada tambahan dari bahan organik lain bisa menyebabkan lahan sawah berkadar bahan organik sangat rendah $(\mathrm{C}$ organic $<2 \%)$. Hal ini akan mengakibatkan penurunan pada produktivitas padi. Tanah rendah bahan organic akan mempengaruhi pada rendahnya efisiensi pemupukan (Las et al., 2002).

Pemupukan merupakan suatu hal yang sangat penting dalam sistem pertanian yang intensif (Setiawan, 2009). ketersediaan unsur hara yang ada di dalam tanah akan berkurang karena unsur hara tersebut diserap oleh tanaman. Keadaan ini mengakibatkan ketidakseimbangan antara penyerapan unsur hara dengan pembentukan hara di dalam tanah. Hara tanah dapat terbentuk lebih baik dengan pemberian pupuk, baik pupuk alami maupun pupuk buatan. Penggunaan pupuk organik bisa memperbaiki sifat fisik, biologi dan kimia tanah (Musnamar, 2003). Sifat fisik, biologi dan kimia tanah yang bagus adalah keadaan lingkungan 
yang berpengaruh positif terhadap pertumbuhan serta hasil panen tanaman budidaya. Bahan organik mempunyai peran yang sangat esensial di dalam tanah serta menjadi faktor utama dalam berbagai proses biokimia dalam tanah. Bahan organik merupakan bahan lengkap gabungan antara makhluk hidup, mati, senyawa organik dan bahan terdekomposisi. Untuk menyediakan unsur hara bagi tanaman yaitu dengan cara menambahkan pupuk organik atau pupuk anorganik merupakan. Selain itu, penyediaaan unsur hara dengan menambahkan pupuk organik maupun anorganik juga mampu memperbaiki sifat fisik, biologi dan kimia tanah (Lumbanraja, 2012; Suriadikarta et al., 2005).

Salah satu jenis pupuk organik yang sekarang banyak di gunakan adalah pupuk bokashi. Bokashi merupakan salah satu cara meggunakan mikroba tanah dalam proses pembuatan pupuk organik dengan menggunakan EM4 (Effective Microorganisme 4) (Indriani, 2011). Bokashi merupakan salah satu jenis pupuk yang bisa menggantikan peranan pupuk kimia (anorganik) dalam menambah dan mempertahankan kesuburan tanah serta memperbaiki kerusakan fisik, biologi, dan kimia tanah yang disebabkan oleh proses pemupukan yang berlebihan. Berdasarkan sumber bahan organiknya, ada beberapa jenis pupuk bokashi yang bisa diaplikasikan oleh petani yaitu, pupuk bokashi kandang, bokashi dari jerami, pupuk bokashi kandang arang dan lain-lain (Raksun, 2018). Pupuk kandang adalah pupuk yang dibuat dari kotoran hewan ternak seperti kuda, sapi, kambing, ayam dan babi yang mempunyai fungsi antara lain: menambah unsur hara tanaman, menambah kandungan humus dan bahan organik tanah, memperbaiki struktur tanah serta memperbaiki jasad renik tanah (Sadjadi et al., 2017). Bahan organik lain yang bisa dimanfaatkan sebagai sumber hara adalah pupuk kandang kotoran sapi. Pupuk organik yang digunakan berasal dari pupuk kandang sapi bisa mengurangi penggunaan pupuk kimia (urea) sebanyak $50 \mathrm{~kg} \mathrm{~N} / \mathrm{ha}$ (Kresnatita et al., 2012).

Bokashi pupuk kandang sapi merupakan salah satu cara dalam mengaplikasikan teknologi pertanian organik yang berkelanjutan serta berwawasan lingkungan. selain itu bokasi feses sapi dapat memberikan manfaat dalam menyediakan unsur hara makro maupun unsur hara mikro bagi tanaman, dapat, memperbaiki struktur tanah, menggemburkan tanah, sehingga mempermudah pertumbuhan akar pada tanaman dalam penyerapan unsur dan hara (Efendi et al., 2017).

\section{KANDUNGAN PUPUK BOKHASI (KOTORAN SAPI)}

Alternatif penerapan teknologi pertanian organik yang berkelanjutan serta berwawasan lingkungan salah satunya dengan penggunaan pupuk bokashi kotoran sapi. Kandungan unsur hara yang tinggi pada kotoran sapi merupakan prospek yang bagus untuk dijadikan pupuk organik (Tufaila et al., 2014). kandungan unsur hara pada kotoran sapi yaitu

Tabel 1 Kandungan Unsur Bokhasi

\begin{tabular}{|l|c|}
\hline \multicolumn{1}{|c|}{ Uraian } & Unsur Hara \\
\hline C organic & $10-18,76 \%$ \\
\hline $\mathrm{N}$ & $0,7-1,30 \%$ \\
\hline $\mathrm{P}$ & $0,52 \%$ \\
\hline
\end{tabular}




\begin{tabular}{|l|c|}
\hline $\mathrm{K}$ & $0,95 \%$ \\
\hline $\mathrm{Ca}$ & $1,06 \%$ \\
\hline $\mathrm{Mg}$ & $0,5-0,86 \%$ \\
\hline $\mathrm{Na}$ & $0,17 \%$ \\
\hline $\mathrm{Fe}$ & $5726 \mathrm{ppm}$ \\
\hline $\mathrm{Mn}$ & $334 \mathrm{ppm}$ \\
\hline $\mathrm{Zn}$ & $122 \mathrm{ppm}$ \\
\hline $\mathrm{Cu}$ & $20 \mathrm{ppm}$ \\
\hline $\mathrm{Cr}$ & $6 \mathrm{ppm}$ \\
\hline $\mathrm{C} / \mathrm{N}$ ratio & $14,0-18,0$ \\
\hline Kadar air & $24,21 \%$ \\
\hline $\mathrm{P} 2 \mathrm{O} 5$ & $1,5-2.0 \%$ \\
\hline K2O5 & $0,5-0,8 \%$ \\
\hline Kadar lengas & $26,28 \%$ \\
\hline Asam humat & $3,42 \%$ \\
\hline Asam fulvat & $2,92 \%$ \\
\hline
\end{tabular}

Sumber : (Irfan et al., 2017; Simanungkalit et al., 2006; Tisdale et al., 1985; Yulipriyanto, 2010).

Pupuk kandang ialah pupuk yang berasal dari kandang ternak, baik berupa kotoran padat (feses) yang tercampur dengan sisa makanan ataupun air kencing (urine), hal ini menyebabkan beragamnya kualitas pupuk kandang tergantung pada umur, jenis dan kesehatan ternak, kadar dan jenis juga pakan yang dikonsumsi, lama dan jenis pekerjaan ternak, kondisi dan lama penyimpanan, jumlah dan kandungan unsur haranya (Soepardi, 1983). Pupuk kandang merupakan pupuk organik yang sering digunakan untuk penambah bahan organik tanah, salah satunya diolah menjadi bokashi pupuk kandang. Pupuk kandang secara kimia dapat menambah unsur hara terutama NPK serta dapat meningkatkan KTK tanah juga secara biologi bisa meningkatkan aktifitas mikroorganisme yang ada pada tanah. Sumber bahan organik yang mudah diperoleh terdapat pada pupuk kandang sapi. Proses penyediaan hara pada pupuk organik terjadi secara perlahan, sehingga dapat menghasilkan dampak residu pada pertanaman selanjutnya, hal ini yang menjadi keunggulan serta kelemahan pupuk organik (Allison, 1973).

Pemberian kompos kotoran sapi dengan dosis 10 ton/ ha-1 (sama dengan $100 \mathrm{~kg}$ N/ha-1, $50 \mathrm{~kg}$ P/ha-1 dan $50 \mathrm{~kg}$ $\mathrm{K} / \mathrm{ha}-1$ ) berpengaruh sangat besar pada pertumbuhan serta hasil panen rumput raja (Sadjadi et al., 2017).

Bokashi merupakan kompos yang dihasilkan melalui proses fermentasi dengan pemberian Effektive Mikroorganisme-4 EM4, yang merupakan salah satu aktivator yang dapat mempercepat proses pembuatan kompos (Roidah, 2013). Perombakan oleh mikroorganisme tanah pada pupuk kandang sapi terjadi beberapa kali hingga menjadi humus bahan organik. Proses pembuatan bokashi dapat terjadi lebih 
cepat dengan pemberian EM4, karena dapat meningkatkan populasi serta keragaman mikroorganisme pengurai (Pangaribuan et al., 2012). Bahan organik yang terdapat pada bokashi apabila dimasukan kedalam tanah dapat menjadi pakan bagi mikroorganisme untuk berkembang biak, sekaliagus penambah persediaan unsur hara bagi tanaman (Zainuddin, 2016)

Keunggulan dan manfaat pupuk organik bokashi yaitu meningkatkan keragaman, populasi dan aktivitas mikroorganisme tanah yang menguntungkan, menekan perkembangan pathogen (bibit penyakit), mengandung unsur hara makro ( $\mathrm{P}, \mathrm{N}, \mathrm{K}, \mathrm{Mg}, \mathrm{Ca}$, dan S) dan unsur hara mikro $(\mathrm{Cu}, \mathrm{Fe}, \mathrm{B}, \mathrm{Zn}$ serta lain-lain), meningkatkan $\mathrm{pH}$ tanah, kandungan humus dalam tanah bertambah, meningkatkan kegemburan tanah, efisiensi penggunaan pupuk anorganik, meningkatkan kesuburan dan produksi tanaman. (Wijaya et al., 2017).

\section{KANDUNGAN UNSUR HARA TANAH PASCA PEMBERIAN PUPUK BOKASHI (KOTORAN SAPI)}

Pengaplikasian pupuk organik terhadap tanaman dapat memperbaiki Corganik tanah lebih tinggi menjadi $4,5 \%$ dibandingkan dengan tanaman tanpa pemberian pupuk organik. (Hafizah \& Mukarramah, 2017). Kandungan unsur hara nitrogen $(\mathrm{N})$, phospor $(\mathrm{P})$, dan kalium (K) pada pupuk organik rendah, namun kandungan unsur hara mikro pada pupuk organik yang diperlukan untuk portumbuhan tanaman sangat berlimpah (Artiana et al., 2016)

Pupuk bokashi bisa memperbaiki sifat fisik tanah melalui pembentukan struktur dan agrerat tanah yang mantap, hal ini berkaitan erat dengan kemampuan tanah dalam infiltrasi air, mengikat air, meningkatkan kapasitas tukar kation, dan pengatur suhu yang berpengaruh baik bagi pertumbuhan serta perkembangan pada tanaman. Sedangkan pupuk majemuk NPK adalah pupuk campuran yang mengandung lebih dari satu macam unsur hara (makro ataupun mikro) terutama N, P dan K (Rosmarkam \& Yuwono, 2002; Tufaila et al., 2014). Pemberian pupuk NPK dapat mencakup beberapa unsur sehingga lebih efisien, hal ini yang menjadi keunggulan pupuk NPK dibandingkan dengan pupuk tunggal (Safei et al., 2014).

Tabel 2 Pengaruh Pemberian Bokashi terhadap Sifat Kimia Vertisol

Hasil analisis bokashi kotoran sapi didapat $\mathrm{C} / \mathrm{N}$ sedikit tinggi yaitu $21 \%$ dari standar kematangan bokashi (1020\%). Agar $\mathrm{C} / \mathrm{N}$ ratio pada bokashi turun dan dapat deserap tanaman maka bokashi diaplikasikan 7 hari sebelum tanam (Rostini et al., 2016). .

\section{PENGARUH PUPUK BOKASHI (KOTORAN SAPI) TERHADAP PERTUMBUHAN TANAMAN}

Tanaman mengalami dua macam pertumbuhan yaitu pertumbuhan tinggi dan pertumbuhan diameter. Pertumbuhan dan perkembangan pada tanaman dipengaruhi oleh ketersediaan energi yang dihasilkan oleh tanaman dari proses fotosintesis (Wahyudin et al. 2016). Selain itu, pertumbuhan tanaman juga dipengaruhi oleh faktor tanah dan faktor iklim seperti suhu, kelembaban, intensitas cahaya, tekstur tanah, sifat fisik dan kimia tanah, KTK, dan ketersediaan unsur hara (Chen et al. 2015). Sifat fisik, biologi serta kimia pada tanah yang baik adalah keadaan lingkungan yang berpengaruh positif pada pertumbuhan serta hasil panen tanaman. Pupuk bokashi bisa mengaktifkan aktivitas sel sel jaringan meristematik tanaman sehingga akan 
menghasilkan anakan produktif yang optimal ( Purwani et al.,1997)

Tabel 3 Pengaruh Pemberian Pupuk Bokashi Terhadap Pertumbuhan Tanaman

Berpengaruh tidaknya pupuk bokashi terhadap tanaman tergantung pada dosis bokashi kotoran sapi yang diaplikasikan. Secara biologi pupuk bokashi bisa meningkatkan aktivitas mikroorganisme yang menguntungkan dan senyawa organik lainnya yang terdapat dalam pupuk bokashi, dan juga bisa meningkatkan keanekaragaman serta aktivitas mikroba dalam tanah sehingga mampu meningkatkan unsur hara dan menunjang pertumbuhan tanaman (tola et al., 2007)

Pupuk bokashi mengandung mikroorganisme bermanfaat yang merupakan bagian penting dari tanah, dapat menyediakan unsur hara pada tanaman melalui proses daur ulang dan membentuk struktur tanah yang sesuai untuk pertumbuhan tanaman (Sumardi et al 2007); (Soplanit dan Soplanit, 2012). Bokashi dapat menyumbangkang unsur $\mathrm{N}$, $\mathrm{P}$, dan $\mathrm{K}$ ke dalam tanah, sehingga bisa meningkatkan ketersediaan unsur-unsur tersebut dalam tanah (syam, 2003; nguyen dan shindo, 2011). Secara kimia bahan organik berfungsi dalam memberikan sumbangan hara melalui dekomposisi.

\section{ANALISIS USAHA TANI PASCA PENGGUNAAN BOKASHI}

Usahatani merupakan suatu ilmu yang mempelajari bagaimana seseorang mengusahakan dan mengkoordinasikan faktor-faktor produksi yang berupa lahan serta alam sekitarnya sebagai modal sehingga memberikan manfaat yang sebaik-baiknya. Kegiatan usahatani pada hakekatnya menjalankan suatu perusahaan, maka sebagai pengusaha, petani senantiasa berupaya untuk memperoleh penerimaan yang melebihi biaya yang dikeluarkan Suratiyah (2006)

Tabel 4 Analisis Usaha Tani Pasca Penggunaan Pupuk Bokashi

Hal ini disebabkan karena pupuk organik mengandung hara yang relatif rendah, sehingga penambahan pupuk organik dalam jumlah yang ralatif tinggi menyebabkan kurang ekonomis (Sutanto, 2002).

\section{KESIMPULAN}

Bokashi dapat digunakan dan berkontribusi untuk meningkatkan kesuburan tanah sehingga memberikan pertumbuhan dan produksi tanaman yang lebih baik. Ditinjau dari finansial, penggunaan bokashi dapat diadopsi sebagai teknologi murah karena sumber daya yang melimpah, biaya murah, aman, efektif, dan mudah beradaptasi dengan petani dalam mengelola praktik pertanian dan lingkungan.

\section{DAFTAR PUSTAKA}

Allison, F. E. 1973. Soil Organic Matter and Its Role in Crop Production. Amsterdam: Elsevier.

Artiana, A., Hartati, L., Sulaiman, A., \& Hadie, J. 2016. Pemanfaatan Limbah Kotoran Sapi dan Jerami Kacang Tanah sebagai Bokashi Cair Bagi Pertumbuhan Tanaman Sawi (Brassica Juncea L.). EnviroScienteae, 12(3), 168-180. Efendi, E., Purba, D. W., \& Nasution, N. U. 2017. Respon Pemberian Pupuk NPK Mutiara dan Bokashi Jerami Padi terhadap Pertumbuhan dan Produksi Tanaman Bawang Merah (Allium ascalonicum L). Bernas, 13(3), 20-29. doi:https://doi.org/10.36294/br.v13 $\underline{\mathrm{i} 3.131}$ 
Hafizah, N., \& Mukarramah, R. 2017. Aplikasi Pupuk Kandang Kotoran Sapi Pada Pertumbuhan dan Hasil Tanaman Cabai Rawit (Capsicum frustescens L.) di Lahan Rawa Lebak. Ziraa'ah Majalah Ilmiah Pertanian, 42(1), 1-7.

Indriani, Y. H. 2011. Membuat Kompos Kilat. Jakarta: Niaga Swadaya.

Irfan, I., Rasdiansyah, R., \& Munadi, M. 2017. Kualitas Bokashi dari Kotoran Berbagai Jenis Hewan. Jurnal Teknologi dan Industri Pertanian Indonesia, 9(1), 23-27.

Kresnatita, S., Koesriharti, K., \& Santoso, M. 2012. Pengaruh Rabuk Organik Terhadap Pertumbuhan dan Hasil Tanaman Jagung manis. The Indonesian Green Technology Journal, 1(3), 8-17.

Las, I., Makarim, A., Toha, H. M., Gani, A., Pane, H., \& Abdulrachman, S. 2002. Panduan Teknis Pengelolaan Tanaman dan Sumberdaya Terpadu Padi Sawah Irigasi (Vol. 37). Jakarta: Badan Penelitian dan Pengembangan Pertanian.

Lumbanraja, P. 2012. Pengaruh Pemberian Pupuk Kandang Sapi dan Jenis Mulsa Terhadap Kapasitas Pegang Air Tanah dan Pertumbuhan Tanaman Kedelai (Glycine max 1) var. Willis Pada Tanah Ultisol Simalingkar. Jurnal Ilmiah Pendidikan Tinggi, 5(2), 58-72.

Musnamar, E. I. 2003. Pupuk Organik Padat: Pembuatan dan Aplikasinya. Depok: Penebar Swadaya. Pangaribuan, D. H., Yasir, M., \& Utami, N. K. 2012. Dampak Bokashi Kotoran Ternak dalam Pengurangan Pemakaian Pupuk Anorganik pada Budidaya Tanaman Tomat. Jurnal Agronomi Indonesia (Indonesian Journal of Agronomy), 40(3).

Raksun, A. 2018. Pengaruh Bokashi

Terhadap Produksi Padi (Oryza Sativa L.). Jurnal Penelitian
Pendidikan IPA, 4(1), 64-67. doi:10.29303/jppipa.v4i1.107

Roidah, I. S. 2013. Manfaat Penggunaan Pupuk Organik untuk Kesuburan Tanah. Jurnal Bonorowo, 1(1), 3043.

Rosmarkam, A., \& Yuwono, N. W. 2002. Ilmu kesuburan tanah. Yogyakarta: Kanisius.

Rostini, T., Ni'mah, G. K., \& Sosilawati, S. 2016. Pengaruh Pemberian Pupuk Bokashi yang Berbeda Terhadap Kandungan Protein dan Serat Kasar Rumput Gajah (Pennisetum purpureum). Ziraa'ah Majalah Ilmiah Pertanian, 41(1), 118-126.

Sadjadi, S., Herlina, B., \& Supendi, W. 2017. Level Penambahan Bokashi Kotoran Sapi terhadap Pertumbuhan dan Produksi pada Panen Pertama Rumput Raja (Pennisetum purpureophoides). Jurnal Sain Peternakan Indonesia, 12(4), 411-418. doi:https://doi.org/10.31186/jspi.id. 12.4.411-418

Safei, M., Rahmi, A., \& Jannah, N. 2014. Pengaruh Jenis dan Dosis Pupuk Organik Terhadap Pertumbuhan dan Hasil Tanaman Terong (Solanum melongena L.) Varietas Mustang F-1. Agrifor, 13(1), 5966.

Setiawan, A. I. 2009. Memanfaatkan Kotoran Ternak. Depok: Penebar Swadaya.

Simanungkalit, R., Suriadikarta, D. A., Saraswati, R., Setyorini, D., \& Hartatik, W. 2006. Pupuk Organik dan Pupuk Hayati (Vol. 312). Bogor: Balai Besar Penelitian dan Pengembangan Sumberdaya Lahan Pertanian.

Soepardi, G. 1983. Sifat dan Ciri Tanah. Departemen Ilmu Tanah. Bogor: Fakultas Pertanian. Institut Pertanian Bogor. 
Suriadikarta, D., Prihatini, T., Setyorini, D., \& Hartatik, W. 2005.

Teknologi Pengelolaan Bahan

Organik Tanah (Vol. 7). Jakarta:

Badan Penelitian dan

Pengembangan Pertanian,

Departemen Pertanian.

Tisdale, S., Nelson, W., \& Beaton, J. 1985.

Soil Fertility and Fertilizer. New

York: Mac Millan Publ. Co.

Tufaila, M., Yusrina, Y., \& Alam, S. 2014.

Pengaruh Pupuk Bokashi Kotoran

Sapi Terhadap Pertumbuhan Dan

Produksi Padi Sawah Pada Ultisol

Puosu Jaya Kecamatan Konda,

Konawe Selatan. Jurnal

Agroteknos, 4(1), 18-25.
Wijaya, R. A., Badal, B., \& Novia, P. 2017. Pengaruh Takaran Bokashi Kotoran Sapi Terhadap Pertumbuhan dan Hasil Tanaman Jagung Manis (Zea mays saccharata). UNES Journal Mahasiswa Pertanian, 1(1), 54-62.

Yulipriyanto, H. 2010. Biologi tanah dan strategi pengelolaannya. Yogyakarta: Graha Ilmu. Zainuddin, A. (2016). Pengaruh Pemberian Bokashi Kotoran Sapi Terhadap Pertumbuhan dan Produksi Rumput Gajah Mini (Pennisetum purpureum cv. Mott). Universitas Hasanuddin, Makassar. 